\title{
Participatory Budgeting in Poland AD 2019: Expectations, Changes and Reality
}

\begin{abstract}
Discussion whether to formalize participatory budgeting or not has been solved. Again, this time it has happened without scholars' engagement. Given this situation, can we say that whoever is satisfied? The amendment of the act that introduced legal form of participatory budgeting as a new tool of public consultation does not meet anyone expectations. The reason to think so is that there is no new and compulsory form of public engagement in financial decisions. Moreover, organizational framework and the huge variety of using participatory budgeting have been turned to uniform pattern. Equally, it is hard to agree that implemented solutions, previously though as a way to increase citizens' involvement in functioning and scrutiny part of public bodies, have been met.
\end{abstract}

Keywords: self-government, participatory budgeting, citizens, financial decisions

\section{Introduction}

One of key elements of Polish local governments is the deficit of partnership culture and dialogue. Partnership culture consists of two elements:

- Multilevel governance, which means that citizens engage in each element of the development policy: from planning to its implementation;

- Social capital, which can be fulfilled with mutual trust and capacity to co-operate on a solidarity basis.

The deficit of partnership culture and dialogue is one of the major threats to local government development (Bober et al., 2013, p. 33). However, citizens' democracy is a form of socio-political community life that is characterized as a huge or increasing citizens' engagement in direct decision-making. The most important factor is citizens' involvement in financial decisions making that shaping revenues and spending of local governments. Political system of the Polish self-government gives priority rather indirect than direct form of democracy. 


\section{Methodology}

The aim of the article is to examine to what extent Amendment Act to Increase Citizens Involvement in Decision Making Process and Scrutiny (further called as Amendment Act or AmAct) might change the position of local governments in terms of participatory budgeting as a new form of public consultations and moreover does it change the way how participatory budgeting is running.

In pursuing this, accepted hypothesis is: Implemented changes in local government act would not exert the influence on the way how local finance will be spent. The reason to think so is the fact that there is a lack of consequence in legal solutions. All in all, it is presented in a nutshell basics characteristic of participatory budgeting and their importance for citizens' democracy development.

The author used institutional-normative research method and desk research in order to check the meaning of amendment legal acts and their influence on the local democracy mechanisms. This article is an attempt to show, in narrow way, political tool that is participatory budgeting. In pursuing this the author shown advantages and disadvantages of this mechanism and explain the way how it is running in democratic realm. Moreover, it is believed that this article presents tangible effects that amendments to Local Government Act may have on selected political processes in Poland.

\section{Expectations}

Participatory budgeting is one of the ways which the civil society can follow. Without further explanation, civil society is a special kind of community, which is consists of citizens who operate in the market economy based on legal rules. In this sense, self- government is both a part of the political system and the civil society (Banaszak, 2006, p. 69; Blicharz, 2012, p. 13-24). The most important fact is that the primary self-government unit - gmina (municipality/commune) is crucial for citizens' engagement, since this is the area where they operate the most. From citizen's perspective, the most important needs are fulfilled at the municipality level; therefore, all legal amendments are so important.

It is obvious that the local government is the best level of public administration, given that there are both the need and possibilities to develop direct democracy tools in terms of financial decisions related to the inhabitants.

It is believed, that there is a sort of interdependence between certain types of local government political systems, as well as public administration and quality of life, which may be defined as a co-relation between a specific type of local government system and citizens' attitude toward engaging into creative and developmental initiatives. It is important to emphasize which kinds of possible actions can be implemented to articulate local community needs and, consequently, how they are put into practice and how long they can last, but not how they are defended (Banaszak, 2006, p. 70). 
Participatory budgeting can be defined as a process, during which citizens decide how to spend some part of the local government budget by means of voting. At the end of the day, citizens choose a certain type of projects or goals, which then are financed by the local budget (Gawłowski, 2019, p. 243)1.

There are numerous advantages of the participatory budgeting, such as:

1. Increasing citizens' influence on local government expenses;

2. Widening citizens' knowledge about local finance, especially in terms of revenue and the way the local finance operates;

3. Improving mutual relations between inhabitants and local administration;

4. Successfully engaging citizens in policy-making processes;

5. Creating certain circumstances enabling citizens to take part in decision-making process in a long run;

6. Stimulating social action, as well as citizens' initiatives (Dworakowska, 2014, p. 57);

7. Facilitating social inclusion, basing on the most important projects;

8. Creating conditions for public debate;

9. Promulgating knowledge about local democracy.

One of the most important aims of citizens' participation is the pursue of balance community interests, which can be defined as a realization of interests of all who participated in the process. Social dialogue and consultations are fertile ground for better socio-economics, as well as the synergy effect, which manifests itself in new ideas for old problems. Social inclusion leads to better implementation, as well as better results, in terms of effectiveness of public service delivery. Another thing is that social engagement results in strengthening citizens' responsibility for public good (Janczulewicz, 2016, p. 304).

Despite the fact that participatory budgeting does not have a long tradition (it is generally accepted to consider that the first budget of this type was implemented in Sopot in 2011 (Kębłowski, 2014,p.4)), some general rules can be seen as target points in the implementation process.

Chart 1. Basic rules and best practices of participatory budgeting:

\begin{tabular}{ll}
\hline Rules in operation & Best practices \\
\hline Citizens submit spending proposal & Only inhabitants have the right to submit their proposals. \\
\hline Some part of the local budget is intended & Participatory budgeting in operation constitutes no less than \\
for participatory budgeting & $0,5 \%$ of the local budget and is annually indexed based on the \\
& part of the budget that was not used in the previous year. \\
\hline
\end{tabular}

1 Literature about participatory budgeting is very broad. To show some examples as follow: Pres, March, 2010; Stoker, 2016; Baiocchi, 1999 and 2003; Hong, 2015; Patsias, Latendresse, Bherer, 2013; Participatory Budgeting, 2008 and newer Polish titles: Gawłowski, Machalski, Makowski, 2019; Gawłowski, Popławski, 2019; Kębłowski, 2014; Poniatowicz, 2014; Sobol, 2017. 


\begin{tabular}{ll}
\hline Rules in operation & Best practices \\
\hline Projects are priced as precisely as possible & $\begin{array}{l}\text { Officers support those who submit projects to participatory } \\
\text { budget (if it is possible and needed). }\end{array}$ \\
\hline Conducting public debates. & $\begin{array}{l}\text { Debates are an essential part of participatory budgeting, } \\
\text { especially during the preparatory process when the projects are } \\
\text { consulted and selected in local area. }\end{array}$ \\
\hline $\begin{array}{l}\text { Submitted projects can be rejected due } \\
\text { to formal reasons, but never on a basis of } \\
\text { merit. }\end{array}$ & $\begin{array}{l}\text { Only the formal part of the projects is analysed; this process } \\
\text { is conducted by a special commission, consisting of officers } \\
\text { and citizens' representatives. There is a special procedure for } \\
\text { rejecting projects. }\end{array}$ \\
\hline $\begin{array}{l}\text { Citizens decide which projects will be } \\
\text { implemented. }\end{array}$ & $\begin{array}{l}\text { There are citizens who decide which projects will be imple- } \\
\text { mented by means of voting or public debate. }\end{array}$ \\
\hline $\begin{array}{l}\text { Only certain part of citizens is allowed to } \\
\text { vote for submitted projects. }\end{array}$ & $\begin{array}{l}\text { Only personal income tax payers and corporate income tax } \\
\text { payers within a given local government are allowed to vote for } \\
\text { submitted projects, as well as individuals who are over 16 years } \\
\text { of age. }\end{array}$ \\
\hline $\begin{array}{l}\text { Projects selected by the citizens are } \\
\text { implemented. }\end{array}$ & \begin{tabular}{l} 
Implementation of certain projects is obligatory. \\
\hline
\end{tabular}
\end{tabular}

Source: Own studies based on Obligatory rules (Gerwin, 2018).

Best practices can be defined as solutions, applied in some places, but not everywhere and taken into consideration during the participatory budgeting implementation.

\section{Amendments Introduced in January 2018}

According to the Amendment Act of January 11, 2018, in order to increase citizens' engagement in electing, functioning and controlling some of the administration offices ${ }^{2}$ (later referred to as "ACT 1"), as well as introducing participatory budgeting in:

- Local Government Act of 8 March 1990 (later referred to as "ACT 2"), Article 5a;

- County Government Act of 5 June 1998 (later referred to as "ACT 3"), Article 3d;

- Regional Government Act of 5 June 1998 (later referred to as "ACT 4"), Article $10 \mathrm{a}$.

The idea of consultations, referendum, and all kinds of citizens' direct engagement in the organization and management is a crucial part of the public domain. This is also mentioned in the European Chart of Local Governments which was drafted by the European Council in 1985 (EKSL 1985, art. 2; Makowski, 2016, p. 34).

ACT 1 contains legal definition of the participatory budgeting as a special form of consultation, revolving around local finance issues. Citizens are allowed to vote annually, in order to decide on how to spend some parts of the local budget. Projects selected this way shall be included in the official local budget. Moreover, during the decision-making process, the local council shall not reject or change such projects (section 4).

2 The Act of January 11,2018, amending certain acts to increase the participation of citizens in the process of selection, operation and controlling of certain public bodies (Dz.U. 2018, pos. 13). 
According to the Local Government Act mentioned earlier, in each local government, participatory budgeting is nothing more than a typical consultation. Therefore, the final results are not obligatory for councilors who decide whether to take it into consideration or not. This is a complete opposite to the main idea of participatory budgeting, which is to implement all projects selected by citizens. Moreover, local administration has had a huge influence on the final results, which can be seen during preparation of additional documents, or verification of formal criteria (Wesołowska, 2016; Giedrys, 2016; Kębłowski, 2014, p. 17-19).

While the applied law states that 'projects selected by means of a participatory budgeting process shall be included within the local budget', there is an issue of strength in terms of how the legal regulations of the participatory budgeting can shape the local budget.

However, participatory budgeting would not become an obligatory decision-making process, implemented by means of direct voting. It seems that the lawmakers were not determined and decisive enough. Only the local governments with county rights will have to introduce participatory budgets (Lachiewicz, 2018). What is worth noting, there is a minimal part of budget that has to be used for participatory budgeting, which equals to $0,5 \%$ of expenses from the last year's financial statement.

It is hard to say what were the reasons behind those law amendments. Introducing obligatory participatory budgeting in local governments with county rights, meaning the biggest cities in Poland, can be seen as a general trend in the European Union. In one of most important publications about cities, Johannes Hahn (member of the European Commission, responsible for regional development) mentions that over two thirds of people in Europe live in cities. There is no better place for science, technology, culture and innovation, as well as development of individual creativity (Miasta, 2011, p. III). The question is, whether the local governments with county rights are seen as a development engine or not - we do not know. However, nobody rises up this argument during the legislative process (Druk, 2018).

Coming back to the main goal of this publication, a huge lack of consistency and determination of the lawmakers can be seen in the next part of the amendments. Art. 1 p. 11 determines that a new article is added (art. 28aa, ACT1), according to which, until 31 May each year, the mayor has to present a report about the local government. This report contains a summary of mayor's activities, in particular in relation to policy implementation, programmes, strategies and local resolutions, as well as the participatory budget (highlight by the author). The same obligations have been implemented in case of counties (art. 2 p.10 adding art. 30a.2, ACT3) and regions (art. 3 p.11 adding art. 34a.2, ACT4).

The first impression is that the participatory budget has a high rank; however, it is another example of the lawmaker's inconsistency and lack of determination. Basing on the fact that participatory budget is obligatory only in local governments with county right, we can say that this is one of the three possible ways of mayor scrutiny! Moreover, after the debate over report, councilors vote for or against the vote of confidence (art. 28aa, ACT2). If councilors decide to reject the vote of confidence twice, it may result in the beginning of 
a referendum, during which the citizens would decide whether or not to call off the mayor. It is worth mentioning, that in fact it can strengthen mayor's political position due to the fact that, after negative result of such vote of confidence, the mayor can implement additional actions to gain positive response in the next year (Pszczyński, Sobczyk, p. 6). If nothing changes, councilors can conduct a referendum. However, it is import to say that, once less than half of the voters vote against the mayor, local council is dissolved according to the law (art. 67, Local Referendum Act). It means that councilors would think twice before they decide to conduct the referendum, due to the fact that they can lose their post. Consequently, amendments to the local government act, in terms of participatory budgeting, strengthen political position of the mayor despite the fact that it has already been very strong.

Due to the differences in political systems between counties and regions, the process of rejection of executive boards is different. If the county council votes against the vote of confidence, consequently it means that the councilors apply to reject the executive board (art.30a.10, ACT3). The same scenario has been introduced in the region (art.34a.10, ACT4). To sum up, we can say that the participatory budgeting amendments, commonly seen as effective tools to engage citizens in public policy, strengthen mayor's political position, which can be found interesting.

Participatory budgeting will be implemented in the same way in local governments, counties and regions. The entry ticket is the Resolution of self-government council (art. 5a.7 ACT2, art. 3d.6 ACT3 and art. 10a.6 ACT4), which should consist of such elements as:

1) Formal requirements for submitting projects;

2) Number of signatures of people supporting the project, but not less than $0.1 \%$ of inhabitants of the certain area

3) Rules, according to which the submitted projects will be assessed, such as: legal rules, technical requirements, process in case of rejection

4) Information on the voting process, considering the transparency of the procedure and equal right to vote.

All found which are devoted for participatory budgeting can be divided for two part. The first one encompasses all self-government unit, but the second one is strictly connected with sub-primary unit or group of them (art. 5a.6 ACT2, art. 3d.5 ACT3 and art. 10a.5 ACT4). It can be said, that the lawmaker guarantees not to introduce too much organizational barriers for the participatory budgeting process. However, it can only be used in local governments with county rights, because only those are obliged to introduce this tool. When it comes to counties and regional government units, the situation is quite different, due to the fact that there is no obligation to introduce participatory budgeting. Therefore, the most important thing is, whether the authorities are open for this kind of initiatives or not.

The Amendment Act came into force on January 31, 2018 (Journal of Laws of January $16,2018)$; however, some parts of this act are postponed. What is worth mentioning, the participatory budgeting will be obligatory for self-governments from the next term. It means that the new budgets will be implemented during the term 2014-2018, especially in relation 
to Art. 5a ACT2, Art. 3d ACT3 and Art. 10a ACT4. Therefore, new resolutions should be prepared by new councils after the 2018 elections and the first meeting of the newly elected councilors (Lechiewicz, 2018). But, what is more, participatory budgets that are in progress right now do not have to be changed until the next election. Moreover, it is agreed that the new law will create new circumstances no sooner than from $2020^{3}$. Citizens can expect more influence on local expenses, if councilors vote for a new resolution, for just two years ${ }^{4}$.

We have to remember that the way citizens can influence the local budget is not precisely defined. The new Self-Governments' Acts does not precise who can submit project proposals, it is hard to acknowledge the article about percentage of collected signatures as a rule defining this issue. Without local government with county rights, there are no information about the level of funding which should be devoted for participatory budgeting in local governments, counties or regional governments. At the end of the day, all specific issues concerning the participatory budgeting will be defined by self-government counties.

We can find more examples which show the lack of determination of lawmakers. The most important thing is that the idea of increasing citizens' influence on the self-government finance is only compulsory in the local governments with county rights. To be more precise, it is worth mentioning that it is not a result of parliamentary debate, during which some consensus has been reached. The final version of the Act remains unchanged during all legislative processes. Therefore, there is no difference between the first parliamentary draft and the Act which has been passed by each of the parliamentary commissions ${ }^{5}$.

\section{Recommendations and Conclusions}

Building a responsive administration and democratic country is based on one major assumption - those who made decisions on each of the processes (passing and implementing law) should be more open for political minorities. There is no better situation if this process is motivated by grassroots movement. All top-down legal initiatives, in terms of consultation process, usually are not effective enough.

Preparation and implementation of participatory budgeting is a complicated process and presents many threats. Therefore, it is very useful to consider such conditions as:

a. Transparency as an essential part during the implementation process

3 Art. 15 ACT1 raises much controversy in terms of „postponing the implementation” of the regulations, which already came into force (Kudra, 2018).

4 K. Ziemski presents a different opinion, by stating: „The goal of the so-called 'drafting' was, most probably, to enable the self-government bodies of this term to prepare appropriate local regulations, necessary for the functioning of newly established Acts. Those Acts shall be prepared, implemented and published in the current term, with indication that they will enter into force according to the Art. 15 of the new Act, i.e. on the first day of the following term" (Ziemski, 2018).

5 See: contents of the Act according to the parliamentary project shared in LEX (www1). 
b. Each step should be planned very carefully

c. Information campaign is crucial to attract as many participants as possible

d. Those who submit project proposals should have the opportunity to find support on the basis of merit

e. It is fruitful to support all variety of projects, especially those which are listed in self-government acts

f. Voting process should be as precise as possible, not to mishap the factual endorsement (Dworakowska, 2014, p. 56).

For a long time, many authors have emphasized that the participatory budgeting should be a compulsory instrument of financial economy in self-governments. Most expectations relate to legal regulations and minimum percentage sum. The most important advantages, in terms of such regulations, are as follows:

- Number of people who take part in the participatory process increases highly;

- Better recognition of inhabitants' needs;

- More accurately financial allocation in terms of citizens' needs and aspirations;

- Increase the sense of direct influence on local issues through local community;

- Citizens' engagement and innovative ideas;

- Decentralization of local power;

- Strengthening direct democracy tools;

- Management transparency of public finance (Hausner et all., 2014, p. 34).

Besides the fact that the mentioned authors show their comments in terms of local governments, it might be considered that all of those positive consequences will appear in other self-government entities. The Amendment Act has a lot of elements which were mentioned in the Report; however, we can only find a handful of proposed changes. Therefore, we are able to highlight that recommendations have stopped half way.

How can we define participatory budgeting?

Some of the researchers focus on the market elements of participatory budgeting, and define it as a tool which allows the local community to participate in the decision-making process, in terms of local finance. However, the right to vote belongs to the inhabitants of a self-government entity (Kołodziej-Hajdo, 2017, p. 164).

There are three elements that make up the participatory budgeting. Firstly, public debate between citizens and local administration representatives. Secondly, citizens co-decide on the use of public finances. Finally, citizens decide on the order of projects' implementation. Nevertheless, there is one more element which might be emphasized here - there is a question whether the projects submitted to a participatory budgeting should be narrowed down or not. If we take into consideration the fact that citizens' subjectivity should be understood as broadly as possible, any limitations might not be implemented whatsoever ${ }^{6}$. However, we have to remember that all of the investment projects submitted to the participatory

${ }^{6}$ In this context, it sounds weird to have such a limitation as „projects which stand in contradiction 
budgeting may be defined as a kind of vote of no confidence. There is no better proof that the local government representatives do not know or even ignore citizens' expectations.

The last thing is the evaluation of the whole project. The main question is whether the primarily established goals have been reached or not. If the answer is negative, there are two possible explanations: the implementation process has been designed improperly or that the primary goals have some kind of mistake. The idea of participatory budgeting was born in the mid-eighties, as a consequence of the resistance movement against the authoritarian political system. Before we learned about it in the beginning of the second decade of XXI century, participatory budgets have developed and changed political circumstances. Nowadays, without any doubts, we can say that it is a commonly accepted tool of public management, implemented in order to increase citizens' engagement. When it comes to Polish experience, it is worth mentioning that participatory budgets have evolved from a bottom-up initiative to a formally oriented tool. The question is, whether this kind of action will strengthen citizens' engagement into local and regional development or not? The formulated hypothesis that amendments in local government law will not influence on the way how local finance is spend, have been acknowledged. Undoubtedly, the reason of it is the lack of clear and explicit legal solutions that would strengthen citizens' democracy realm.

All mentioned inconsequences, scarcities and nonadherences, encourage us to think about the future more cautiously. It is very hard to predict the final results, because everything is up to a ballot cast into the ballot box.

\section{References}

Baiocchi, G. (1999). Participation, activism, and politics: the Porto Alegre experiment and deliberative democratic theory. University of Wisconsin-Madison.

Baiocchi, G. (2003). Emergent public spheres: talking politics in participatory governance. American Sociological Review No. 1.

Banaszak, N. (2006). Lokalne społeczeństwo obywatelskie a dezintegrujace determinanty prawne. Rozważania teoretyczne. Studia Lubuskie, No. 2.

Blicharz, J. (2012). Administracja publiczna i społeczeństwo obywatelskie w państwie prawa. Wrocław.

Bober, J. et al. (2013). Narastające dysfunkcje, zasadnicze dylematy, konieczne działania. Raport o stanie samorządności terytorialnej w Polsce. Kraków.

Druk nr 2001 Poselski projekt ustawy o zmianie niektórych ustaw w celu zwiększenia udziału obywateli w procesie wybierania, funkcjonowania i kontrolowania niektórych organów publicznych. Uzasadnienie, (2018.05.30). Retrieved from: http://www.sejm.gov.pl/Sejm8.nsf/druk.xsp?nr=2001.

Dworakowska, M. M. (2014). Budżet partycypacyjny w zarządzaniu finansami jednostek samorzadu terytorialnego w Polsce. Zeszyty Naukowe Uniwersytetu Szczecińskiego, No. 841, Ekonomiczne Problemy Usług, No. 115.

to the plans and programmes present in the city, including, in particular, the spatial development plans, industrial programmes, long-term financial forecast etc.", par. 13 point 3 (Terms and Conditions, 2013). 
Europejska Karta Samorządu Lokalnego z 15 października 1985r. (1985). Dz.U. z 1994r. nr 124, poz. 607 z późn. $z m)$.

Gawłowski, R. (2019). Partycypacja społeczna. In Gawłowski R., Machalski P., Makowski K., Samorząd terytorialny w systemie administracji publicznej. Warsaw: CeDeWu.

Gawłowski, R., Popławski, M. (2019). Regionalne Budżety obywatelskie - powielanie, inspiracja czy nowa konstrukcja?. Samorząd Terytorialny, No. 1-2.

Gerwin, M., (2018.05.29). 8 kryteriów budżetu obywatelskiego. Retrieved from: http://www.sopockainicjatywa.org/2013/01/31/8-kryteriow-budzetu-obywatelskiego/\#more-19036.

Giedrys, W., (2016.03.22). Czy torunian nie interesuje budżet obywatelski? Retrieved from: http://ddtorun. pl/pl/11_wiadomosci/3543_czy_torunian_nie_interesuje_budzet_obywatelski.html.

Hausner, J. et al. (2014), Narastajace dysfunkcje, zasadnicze dylematy, konieczne działania. Raport o stanie samorząności terytorialnej w Polsce. Tom II. Kraków.

Hong, S. (2015). Citizen Participation in Budgeting: A Trade-Off between Knowledge and Inclusiveness? Public Administration Review, No. 4

Janczulewicz, K. (2016). Budżet obywatelski narzędziem dialogu społecznego. Idea partycypacji w społeczeństwie informacyjnym. In Batorowska H., Kwiasowski Zb., Kultura informacyjna w ujęciu interdyscyplinarnym-teoria i praktyka. tom 2, Kraków.

Kębłowski, W. (2014). Budżet partycypacyjny. Ewaluacja. Warsaw.

Kołodziej-Hajdo, M. (2017). Budżet partycypacyjny jako instrument zarzadzania publicznego w koncepcji public governance na przykładzie miasta Krakowa. Studia Ekonomiczne. Zeszyty Naukowe Uniwersytetu Ekonomicznego w Katowicach, No. 341.

Kudra,A.(2018.02.13). Pozostało kilka miesięcy na uwzględnienie zmian prawnych $w$ statutach jst. Retrieved from: http://prawodlasamorzadu.pl/2018-01-29-pozostalo-kilka-miesiecy-na-uwzglednieniezmian-prawnych-w-statutach-jst.

Lachiewicz, W. (2018.05.07). Czy w związku ze zmiana przepisów ustawy o samorządzie powiatowym, które weszły w życie 31 stycznia 2018 r., Starostwa Powiatowe obligatoryjnie musi utworzyć tzw. budżet obywatelski od 2019 r.? A może nadal jest to zadanie fakultatywne dla powiatu? Retrieved from: https://sip-1lex-1pl-1zmhiawpe0021.else.wsb.torun.pl/\#/question-and-answer/621797010/czysamorzad-powiatowy-zobowiazany-jest-uchwalic-budzet-powiatu-na-rok-2019-z-uwzglednieniemtzW...? $\mathrm{cm}=$ RELATIONS.

Makowski, K. (2016). Władze samorządu lokalnego w Europejskiej Karcie Samorzadu Lokalnego. In Eds. Gliniecka J., Drywa A., Juchniewicz E., Sowiński T., Finansowanie samorzadu terytorialnego i jego zadań a Europejska Karta Samorządu Lokalnego. Warsaw: CeDeWu.

Miasta przyszłości. Wyzwania, wizje, perspektywy. Unia Europejska 2011.

Piróg, T. (2017). Obywatelski wymiar samorządności terytorialnej. In Piróg T. (ed), Oblicza polskiej samorządności. Wyzwania i praktyki rządzenia. Kraków: ZW Nomos.

Participatory Budgeting: a draft national strategy. Giving more people a say in local spending. Department of Communities and Local Government, March 2008.

Patsias, C., Latendresse, A., Bherer, L. (2013). Participatory Democracy, Decentralization and Local Governance: the Montreal Participatory Budget in light of 'Empowered Participatory Governance'. International Journal of Urban and Regional Research, No. 6

Poniatowicz, M. (2014), Kontrowersje wokót idei budżetu partycypacyjnego jako instrumentu finansów lokalnych. Studia Ekonomiczne - Zeszyty Naukowe Wydziałowe, No. 198.

Pres, M., March, H. (2010). Short Guides for Citizen Participation, Guide to Evaluating Participator Processes. New York. 
Pszczyński, M., Sobczyk, P. (2018). Nowelizacja przepisów samorządowych i wyborczych - aspekty prawne i praktyczne istotne dla jednostek samorzadu gminnego. Ekspertyzy i Opracowania, No. 38.

Regulamin budżetu partycypacyjnego w Toruniu, Załacznik do uchwały nr 655/13 Rady Miasta Torunia $z$ dnia 21 listopada 2013 r., (2018.05.29). Retrieved from: http://www.bip.torun.pl/dokumenty. php?Kod=12127.

Sobol, A. (2017). Budżet obywatelski jako narzędzie rozwoju lokalnego. Studia Ekonomiczne. Zeszyty Naukowe Uniwersytetu Ekonomicznego w Katowicach, No. 316.

Stoker, G. (2016). Why politics matters: making democracy work. London: Palgrave Macmillan.

Ustawa (1) z dnia 11 stycznia 2018 r. o zmianie niektórych ustaw w celu zwiększenia udziału obywateli $\mathrm{w}$ procesie wybierania, funkcjonowania i kontrolowania niektórych organów publicznych, Dz.U.2018, poz. 13.

Ustawa (2) z dnia 8 marca 1990 r. o samorządzie gminnym, Dz.U. $1990 \mathrm{Nr}$ 16, poz.95 z późn. zm.

Ustawa (3) z dnia 5 czerwca 1998 r. o samorządzie powiatowym, Dz.U. 1998 Nr 91, poz.578 z późn. zm.

Ustawa (4) z dnia 5 czerwca 1998 r. o samorządzie województwa, Dz.U. Nr 91, poz.576 z późn. zm.

Ustawa (5) z dnia 15 września 2000 r. o referendum lokalnym, Dz.U. $2000 \mathrm{Nr} 88$ poz. 985 z późn. zm.

Wesołowska,A.(2016.03.22). Co dalej z budżetem obywatelskim?, Grozi mu zmiana w plebiscyt”, Retrieved from: http://ddtorun.pl/pl/11_wiadomosci/3592_co_dalej_z_budzetem_obywatelskim_grozi_mu_ zmiana_w_plebiscyt.html.

www1 (2018.05.07). Retrieved from: https://sip-1lex-1pl-1zmhiawpe0021.else.wsb.torun.pl/\#/actproject/102536771/3/zmiana-niektorych-ustaw-w-celu-zwiekszenia-udzialu-obywateli-w-procesiewybierania-funkcjonowania...? $\mathrm{cm}=$ RELATIONS.

Ziemski, K. (2018.02.21). Zmiany w statutach JST jeszcze $w$ tej kadencji. Retrieved from: http://prawodlasamorzadu.pl/2018-02-21-zmiany-w-statutach-jst-jeszcze-w-tej-kadencji.

\section{Author}

\section{Krzysztof Makowski}

PhD, WSB University in Toruń. Contact details: krzysztof.makowski@wsb.torun.pl 